\title{
CONTROL OF RAW MATERIAL SUPPLY WITH BILL OF MATERIALS IN PT SINAR METRINDO PERKASA
}

\author{
Destyanto Anggoro Wahyu Jatmiko and Sri Poernomo Sari \\ Department of Mechanical Engineering, Gunadarma University, Indonesia
}

\begin{abstract}
Production planning and control can be used as a reference or guideline in conducting production activities. With the existence of good production planning and control, the company can minimize or anticipate things that are detrimental to the company, so that optimal profits can be obtained by the company. The problem that occurs is PT. Sinar Metrindo Perkasa has not used the right forecasting method to predict the sales of electrical panels that continue to fluctuate. Often there is a lack of production in the company does not know the planning of raw materials for further production. Forecasting results can be used to compile production activities and operations of the company, such as in terms of raw material inventories, namely looking for safety stock or making a standard bill of material that is useful to know for further planning. Forecasting with 3 methods for evaluating forecasting using the sum of absolute errors. Mean Absolute Deviation (MAD) measures the accuracy of predictions by averaging estimated errors. MAD weight moving average is 152662.3 data, single exponential smoothing 112749.3 data and simple linear regression 83282.52 data. Then on the BKA and BKB the results obtained by the BKA in October were equal to 32,837 and the $B K B$ value of $-32,837$, the average of the results of the moving range of 123,449. The graphic image on the $x$-axis line is the number of periods or months and the y-axis value of the number of forecasting lines BKA has uniform data because the value of the data distribution of material purchases is close to the BKA means that the percentage value of material purchases during the year is problematic and vice versa with $B K B$ uniform data because the value of the data spread is close to the average. For this forecasting, further research can be done by finding a bill of material for each order and also looking for control of the production with safety stock.
\end{abstract}

Keywords: Forecasting, Mean Absolute Deviation, Inventory Control.

Cite this Article: Destyanto Anggoro Wahyu Jatmiko and Sri Poernomo Sari, Control of Raw Material Supply with Bill of Materials in PT Sinar Metrindo Perkasa, International Journal of Industrial Engineering Research and Development, 10 (1), 2019, pp. 1-9. https://iaeme.com/Home/issue/IJIERD?Volume=10\&Issue=1 


\section{INTRODUCTION}

Companies experience demand fluctuations continuously from time to time, in the face of this the company needs to do production planning well. Production planning and control can be used as a reference or guideline in conducting production activities. With the existence of good production planning and control, the company can minimize or anticipate things that are detrimental to the company, so that optimal profits can be obtained by the company.

The problem that occurs is PT. Sinar Metrindo Perkasa has not used the right forecasting method to predict the sales of electrical panels that continue to fluctuate. Often there is a lack of production in the company does not know the planning of raw materials for further production. In addition, companies also often experience excess capacity in production, which results in losses such as the amount of inventory costs for storing these products, if this continues to be allowed the company cannot do production planning and control properly. And the maximum profit cannot be obtained by the company. It takes an appropriate forecasting method, with a small level of forecasting errors, which can project the future with a forecasting value that is not much different from the actual demand data. Forecasting results can be used to compile production activities and operations of the company, such as in terms of raw material inventories, namely looking for safety stock or making a standard bill of material that is useful to know for further planning.

\section{STUDI OF LITERATURE}

Inventory are idle resources to wait for further processing, such as a production activity in the manufacturing system and marketing activities in the distribution system. In addition, it is also said as goods that are stored and will be used to fulfill a certain purpose, for example manufactured goods, resale goods, and goods spare parts of an equipment ${ }^{[1]}$

Inventory can appear because it is planned or is a result of ignorance of information. So, there are companies that have inventory because they intentionally make products earlier or more than the time and amount to be sent or sold at a certain time, there are also because it is a result of requests that are too little compared to the initial estimates. This uncertainty is also experienced by many companies operating with the make to stock system. In fact, many companies will face very high uncertainties, so that they can have enough inventory at the end of the sale period. Inventory also arises due to economic motives in carrying out a production or shipping activity. The factory will not be able to produce too little because it will not achieve what is called an economic scale (economic of scale) ${ }^{[2]}$

Forecasting is the first activity in determining the production schedule in the future. Forecasting is based on the determination (prediction) of the demand for a product which will then be used as a production target. There are two categorization of forecasting methods namely qualitative and quantitative techniques. This qualitative technique is used if past data is not available or even though it is available but the amount is not sufficient according to what is needed. Qualitative techniques combine information with experience, judgment, and intuition to produce patterns and relationships that might be applied in predicting the future. Qualitative techniques are based on common sense approaches in filtering information into useful forms. Some of the methods included in qualitative techniques include visionary, consensus panels, brainstorming, antipatory surveys, role playing, and others. Qualitative techniques are most suitable to be applied in two conditions, namely when there is no or lack of quality quantitative data. For example, in forecasting opportunities for new products or markets and there is sufficient quantitative data, there are certain factors that cause qualitative techniques to be more suitable to be applied. For example, even though there is sufficient data on the historical condition of the Indonesian economy, non-economic conditions (politics and so on) greatly affect the situation in the future. Whereas limitations such as empirical evidence indicate that 
different results can arise if different information collection methods are used, there is a possibility of overconfidence judgments. There is a "groupthink" phenomenon where thoughts that deviate from group consensus will be suppressed. The effect of groupthink is the reduction of critical opinions ${ }^{[3]}$

The first mean absolute deviation (MAD) is a measure of error calculated by taking the absolute number of each forecasting error with the number of periods of data $(n)^{[4]}$.

$$
\mathrm{MAD}=\frac{\sum(\text { Absolut dari forecast error })}{\mathrm{n}}
$$

Second, mean square error (MSE) is a measure of forecasting error calculated by the number of error squares divided by the number of periods ${ }^{[4]}$

$$
\mathrm{MSE}=\frac{\sum(\text { dari forecast error })}{\mathrm{n}}
$$

Third, mean absolute percentage error (MAPE) is the absolute percentage average of forecasting errors by calculating absolute errors per period. This error is then divided by $\mathrm{n}^{[4]}$

$$
\text { MAPE }=\frac{\sum\left|\frac{E}{X i}\right|(100)}{n}
$$

Fourth, tracking signal is a measure of how best a forecast predicts actual values. The formula used to determine the tracking signal ${ }^{[4]}$

$$
\mathrm{TS}=\frac{\text { RSFE Kumulatif }}{\mathrm{MAD}}
$$

Finally, the method used to compare the value of the actual data with the forecasting value of the same need is to calculate the value of the moving range ${ }^{[4]}$

$$
\text { MR absolute } \left.=\left|\left(\mathrm{F}_{\mathrm{t}-1}-\mathrm{A}_{\mathrm{t}-1}\right)-\left(\mathrm{F}_{\mathrm{t}}-\mathrm{A}_{\mathrm{t}}\right)\right| \mathrm{A}_{\mathrm{t}}\right) \mid
$$

Product structure or bill of material (BOM) is defined as the way the components are joined into a product during the manufacturing process. The bill of material used for production planning is often referred to as the planning bill of materials (planning BOM) or often abbreviated as planning bill. The planning bill is divided into the first two planning bills with scheduled items which are components or subassemblies for the production of the final product, where the scheduled items are physically smaller than the final product (end items) ${ }^{[4]}$

Standard Bill Of Quantity Material Information System is an information system that is a place for a set of production plans for bill of material with the aim of planning production processes starting from material procurement, order ordering schedule using EOQ method as a basic principle in the process of scheduling material orders, avoiding running out stock in the storage warehouse, and control the course of the bill of material that goes down to the production section in the form of generator material data such as baseframe bomb data, coupling bomb data, canopy bomb data, wiring engine bomb data, data wiring engine panel, panel data, tank data solar, data silencers, and data finishing ${ }^{[5]}$ 


\section{METHODOLOGY}

Flowcharts are used to analyze, design, document or manage a process or program in various fields.

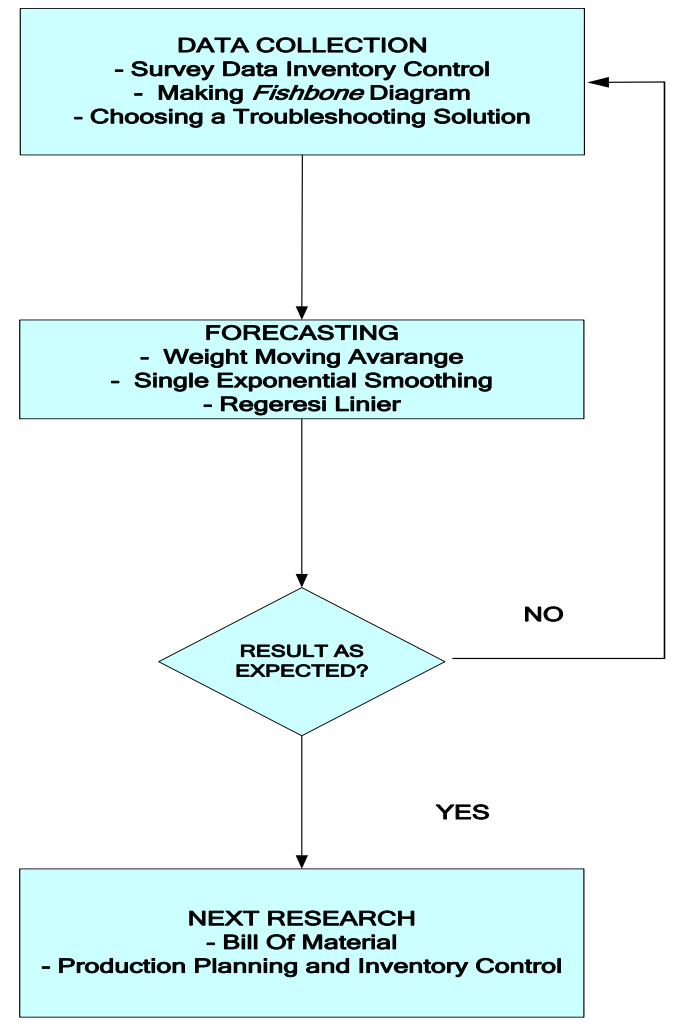

Figure 1 Flowchart Problem Inventroy Control

The first step is collecting data at PT. Sinar Metrindo Perkasa. There are several planned stages of data collection, first is to survey raw materials in the company. The survey was conducted to collect all material data in the warehouse, then order size data for panels that are commonly used. The second data collection is studying the problems that occur in the inventory system in the form of constraints on the inventory system in the company. The third data collection chooses a solution in solving a good problem. This forecasting uses three methods, namely weight moving avatar, single exponential smoothing and linear regression which serves to see an increase in sales for one year based on the use of raw materials. The next step for further research is to make a bill of material that serves to control raw materials, one of which is safety stock.

\section{DISCUSSION}

The completion of this discussion is the first step that is done using a causal diagram because the company wants to know the cause of the problem in the PPIC (Production Control and Inventory Control) section, especially in the raw material inventory in the company. The discussion of fishbone is used to find out how many factors of each problem are described through fish bones and find the root of the problem. 


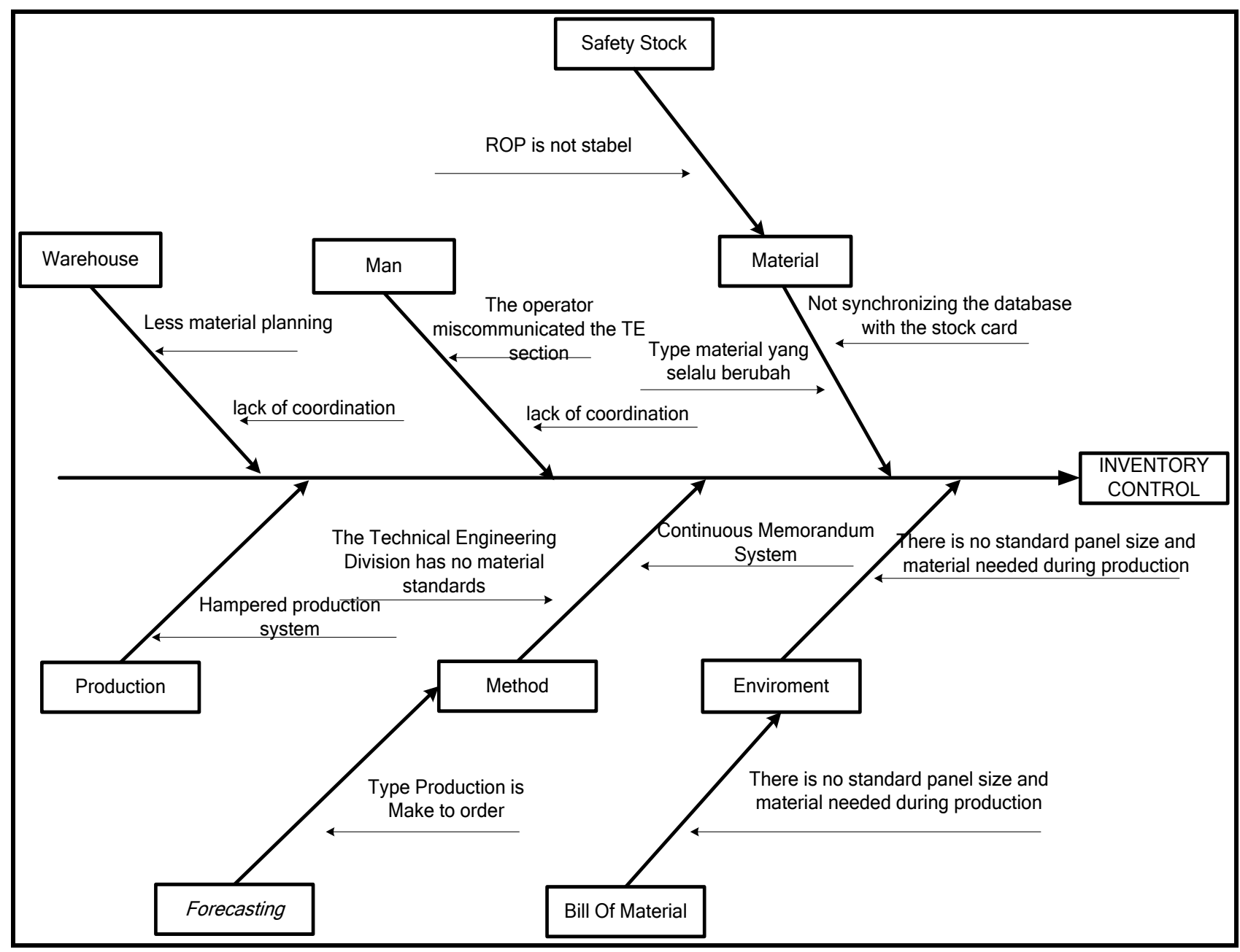

Figure 2 Fishbone Problem Inventory Control of PT Sinar Metrindo Perkasa

Problems PT Sinar Metrindo Perkasa are described using a fishbone system that serves to find out what causes that occur in the company in raw material inventory systems in warehouse. Based on the causal diagram above, there are several factors that can lead to inventory control. These factors are material, machine, human and method factors. The following is an explanation for each of the factors causing the failure of the process. The human factor in the causes of inventory control is caused by the operator's miscommunication with the TE section. This is because between the warehouse or warehouse with production must be mutually communication because if there is lack of communication or coordination of the occurrence of shortages when taking material in the warehouse. Then the operator miscalculates forecasting because the operator incorrectly estimates the order which results in the accumulation and shortage of material. Material factors in the process of producing electrical panels, material is also a determining factor in the smoothness of a production. One of the problems in inventory control is out of sync with the stock card. This is because the material distribution and data collection system uses stock cards and software that uses accurate. Sometimes the results of the data collection are still less accurate than accurate and the stock of goods which results in incompatibility with the number of goods in the warehouse so that the production process is hampered. Then the material is unstable because the production process is make-to-order and does not have a standard so it makes the goods unstable on the safety stock which sometimes accumulates or lacks. Environmental factors are a factor in late delivery of raw materials. This is due to the fact that the raw material purchasing system still predicts the delivery time or lead 
time which results in late shipments. Another case on the part of the supplier is to extend the delivery time because the order period is violated in accordance with the agreement. The method factor has an influence on inventory control, namely the system used in the company. The company still uses a memorandum system on the distribution of material that has been estimated by the TE (Technical Engineer) section because the part that composes or improves the team drafter. Likewise the problem is because the TE does not have a standard that is used for each panel requiring any material to be used so as not to keep a memorandum of management so that the warehouse must store more raw materials and if the raw material is not used it will cause the price to rise. The production factor has an influence or problem on production because abnormal inventory systems are hampered by the production system or work on panel products. The inhibition of this production system is due to lack of coordination with the warehouse or warehouse section with the production team. Warehouse factor has less effect on material planning because their inventory system is still not regular in terms of production control and inventory control so that there are still goods or materials that are late in arrival or warehouse stock has run out. Then the next problem is caused by a lack of coordination between the warehouse division and the production division which results in the production process being hampered. Forecasting factors have an influence on the warehouse and production if the division does not regulate well about its inventory, it will hamper the production system in the company. One example of the problem is that the production system in this company uses make to order, making it difficult to forecast the next production. The bill of material factor has an influence on the standardization of needs in production. Standardize in the example size of the panel form when making the previous order. The safety stock factor has an influence on the reorder point that is less stable because there is no prior planning on the company's estimated purchases and expenses. Because the production purchasing system in this company is make to order that produces when getting a booking so that there is no structured planning in the material.

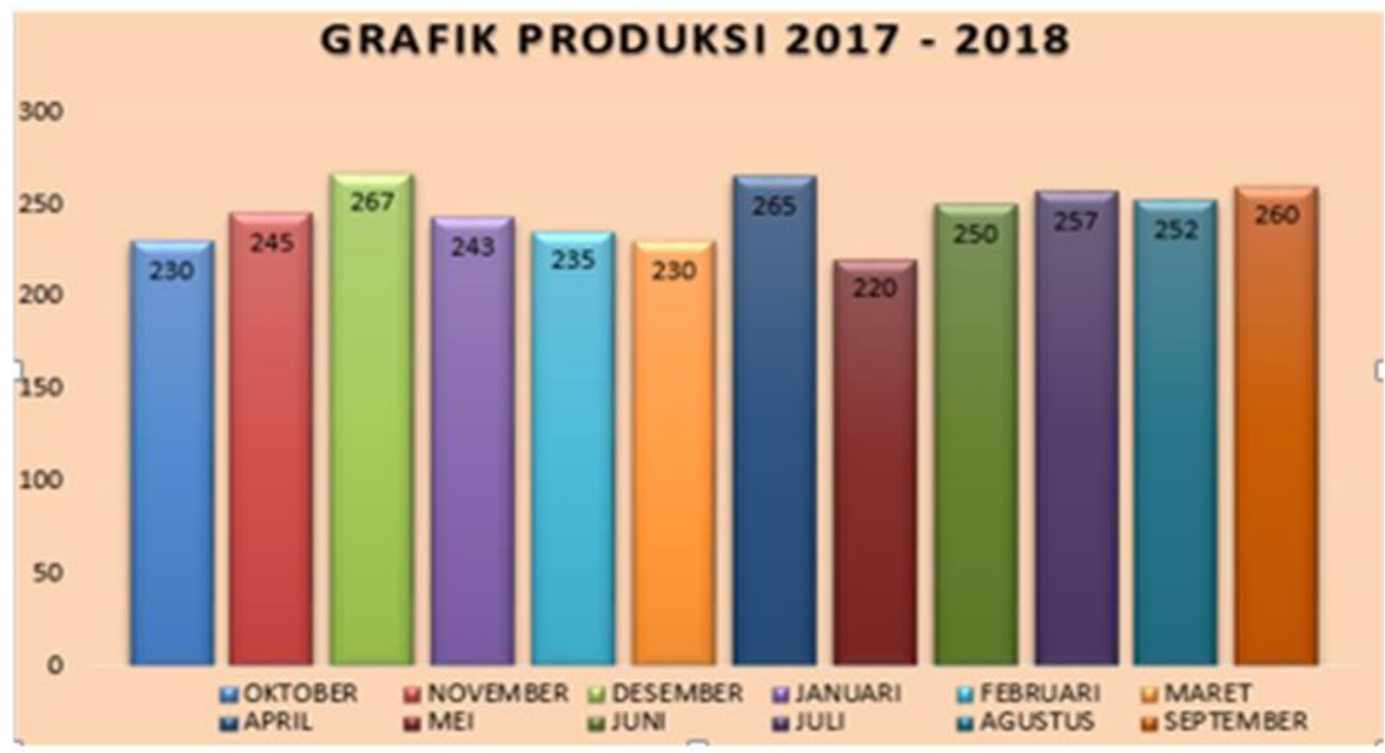

Figure 3 Electrical Panel Product

This graph shows the making of electrical panel products that function to find out how many electrical panels are made with the needs of raw materials used during the production process. This graph shows the production process of the last 12 months from October 2017 to September 2018. PT Sinar Metrindo Perkasa conducts production based on orders or requests received. Orders received affect the inventory that must be prepared. There is a definite demand, a clear inventory cost and there is a lead time to make inventory at PT Sinar Metrindo Perkasa has a 
deterministic inventory system. All parameters and variables are known or can be calculated with certainty. Inventory of raw materials carried out by PT Sinar Metrindo Perkasa considers that the inventory position of raw materials is a deterministic inventory system but the number of orders made each time a message is added with a reserve of safety inventory. This is to anticipate and reduce demand fluctuations. The following types are often produced on electrical panels.

\section{RESULT}

After calculating the forecasting with the three methods, it is necessary to do a comparison of each of these methods, so that the stability of the results of the process can be controlled properly so that it can be done using the moving range method.

Table 1 Forecasting

\begin{tabular}{|l|l|}
\hline \multicolumn{1}{|c|}{ Method } & \multicolumn{1}{c|}{ Result MAD } \\
\hline Weight Moving Average & 152662,3 \\
\hline $\begin{array}{l}\text { Single Exponential } \\
\text { Smoothing }\end{array}$ & 112749,3 \\
\hline Regresi Linier & 83282,52 \\
\hline
\end{tabular}

Mean Absolute Deviation (MAD) merupakan dari selisih penjualan dan peramalan bisa sama dengan nol, namun error bisa muncul cukup besar pada periode tertentu. Perhitungan ini dilakukan berdasarkan nilai MAD terkecil dari ketiga metode peramalan yang digunakan. Nilai MAD terkecil terdapat pada metode regresi linear, sehingga perhitungan moving range dilakukan menggunakan hasil peramalan metode regresi linear.

Example Moving range (MR) pada bulan Oktober

Table 2 Mean Deviation

\begin{tabular}{|c|c|c|c|c|c|}
\hline No & Month & $\begin{array}{c}\text { Forecasting } \\
(\mathrm{F})\end{array}$ & $\begin{array}{c}\text { Actual Selling } \\
(\mathrm{A})\end{array}$ & A-F & MR Absolute \\
\hline 1 & Oct & 1.654 .464 & 1.729 .428 & 74.964 & - \\
\hline 2 & Nov & 1.740 .368 & 1.738 .457 & -1.911 & 65.953 \\
\hline 3 & Dec & 1.920 .338 & 1.747 .486 & -172.852 & 10.940 \\
\hline 4 & Jan & 1.715 .975 & 1.756 .514 & 40.539 & 181.880 \\
\hline 5 & Feb & 1.650 .992 & 1.765 .543 & 114.551 & 31.510 \\
\hline 6 & March & 1.814 .400 & 1.774 .572 & -39.828 & 105.552 \\
\hline 7 & April & 1.913 .744 & 1.783 .600 & -130.144 & 48.856 \\
\hline 8 & May & 1.602 .992 & 1.792 .629 & 189.637 & 139.173 \\
\hline 9 & June & 1.856 .176 & 1.801 .658 & -54.518 & 180.608 \\
\hline 10 & July & 1.891 .344 & 1.810 .668 & -80.676 & 63.528 \\
\hline 11 & Aug & 1.739 .712 & 1.819 .715 & 80.003 & 89.723 \\
\hline 12 & Sept & 1.848 .528 & 1.828 .744 & -19.784 & 70974 \\
\hline \multicolumn{5}{|c|}{ Total } & 1.357 .949 \\
\hline
\end{tabular}

moving range $(\overline{M R})=\frac{\sum M R}{n-1}=\frac{1.357 .949}{12-1}=123,449$

(BKA) upper control limit

$$
\begin{aligned}
& =2,66 \times \overline{M R}=2,66 \times 123,449=32,837 \\
& =-2,66 \times \overline{M R}=-2,66 \times 123,449=-32,837
\end{aligned}
$$

(BKB) bottom control limit

In the above calculation example, it is calculating the moving range in October which is obtained by absolute MR which can be known by knowing the error rate in the relevant data month by subtracting actual sales data with predetermined prediction so that it has a minus result which means data error or deviate from average. Then on the BKA and BKB the results obtained by the BKA in October were equal to 32,837 and the BKB value of $-32,837$, the average of the results of the moving range of 123,449 . The graphic image on the $\mathrm{X}$-axis line is 
the number of periods or months and the y-axis value of the number of forecasting lines BKA has uniform data because the value of the data distribution of material purchases is close to the BKA means that the percentage value of material purchases during the year is problematic and vice versa with $\mathrm{BKB}$ uniform data because the value of the data spread is close to the average. Test results obtained from forecasting for one year have data that is not uniform because in the graph shows the percentage passing above the average BKA and BKB. The figure below is a moving range graph.

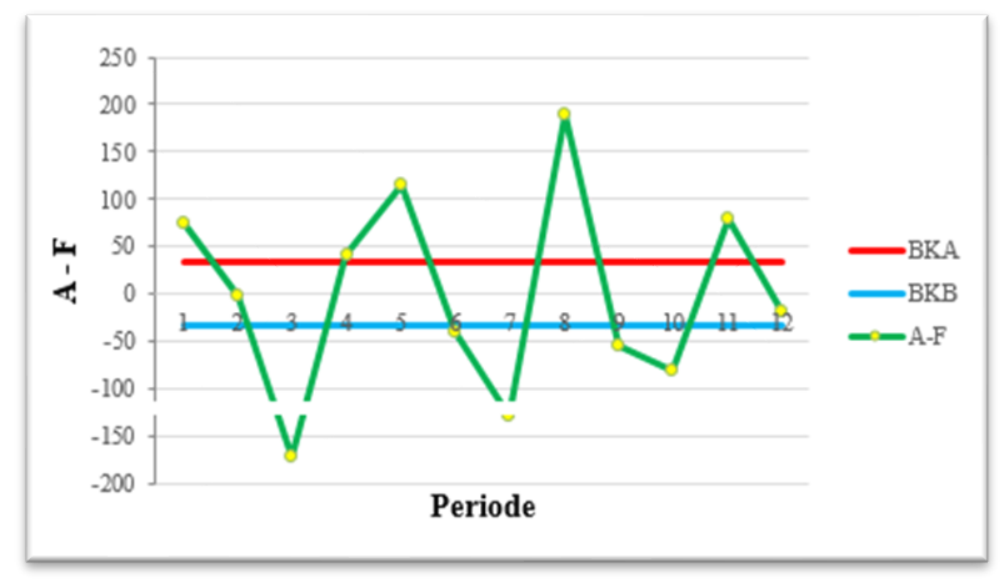

Figure 4 Moving Range Maps

Based on the map moving range takes data with a linear regression method. Based on the fluctuating chart form, it is included in the category of cyclical graphs. It also explains that raw material purchase planning has the largest purchase in May 2018, which is based on the number of panel production that requires a lot of raw material. Moving range is used as a tool to perform a forecasting control or tool to pay attention to a data stability on a function or forecasting method used, in this report the moving range is calculated based on the results of the linear regression forecasting method. Based on the graph, it can be seen that all points are within the control limit or do not come out from the upper and lower limits, so it can be assumed that the sales forecasting produced is good enough for several periods or months using linear regression methods with MAD values. For this forecasting, further research can be done by finding a bill of material for each order and also looking for control of the production with safety stock.

\section{CONCLUSION}

Forecasting with 3 methods, namely weight moving average, single exponential smoothing and simple linear regression with POM QM software for Windows. The method for evaluating forecasting uses the sum of absolute errors. Mean Absolute Deviation (MAD) measures the accuracy of predictions by averaging estimated errors. MAD weight moving average is 152662.3 data, single exponential smoothing 112749.3 data and simple linear regression 83282.52 data. Then on the BKA and BKB the results obtained by the BKA in October were equal to 32,837 and the $\mathrm{BKB}$ value of $-32,837$, the average of the results of the moving range of 123,449 . The graphic image on the $\mathrm{x}$-axis line is the number of periods or months and the $y$ axis value of the number of forecasting lines BKA has uniform data because the value of the data distribution of material purchases is close to the BKA means that the percentage value of material purchases during the year is problematic and vice versa with BKB uniform data because the value of the data spread is close to the average. For this forecasting, further research can be done by finding a bill of material for each order and also looking for control of the production with safety stock. 
Destyanto Anggoro Wahyu Jatmiko and Sri Poernomo Sari

\section{REFERENCES}

[1] Rangkuti, Freddy. 2007. Manajemen Persediaan Aplikasi dibidang Bisnis. PT. Raja Grafindo Persada. Jakarta.

[2] Pujawan, I Nyoman. 2017. Supply Chain Management Edisi 3. ANDI. Yogyakarta.

[3] Munawaroh, A. Nurhayati, Peramalan Jumlah Penumpang Pada PT. Angkasa Pura I (Persero) Kantor Cabang Bandar Udara Internasional Adisutjipto Yogyakarta Dengan Metode Winters Exponential Smoothing dan Seasonal Arima,eprints.uny.ac.id/1430/2/SKRIPSI_LENGKAP.pdf, 07 April 2018.

[4] Gasperz, Vincent. 2004. Production Planning and Inventory Control. Jakarta: PT Gramedia Pustaka Utama.

[5] Cahyono, Dwi Dkk. 2017. Sistem Informasi Standard Bill of Material Quantity Genset di PT Conductorjasa Suryapersada. Universitas Dr.Soetomo. Surabaya 